\title{
QUO VADIS RASIONAL CHOICE DALAM PILKADA ACEH BARAT MENUJU 2017
}

\author{
Alimas Jonsa \\ Fakultas Ilmu Sosial dan Ilmu Politik, Universitas Teuku Umar \\ email: alimasjonsa@gmail.com
}

\begin{abstract}
The title of this study is Quo Vadis Rational Choice in the Election Aceh Barat in 2017.The reason for choosing such title was because the election western district of aceh in 2017 so unique and diverse calonnya will start of a candidate backed by national party, local party and the independent. But in this case researchers want to assess fenomen what is mean by quo vadis rational choice in for the section kabupataen aceh barat. Social phenomenon in behavior choose quo vadis rational choice in local election district of aceh western in transition toward democracy in 2017 in determining voting. Methods used in this research is a method of the qualitative study, where needed was an understanding of social phenomena, so as to become the focus of major is acquire understanding of at the action and meaning social trend in the viewing angle the subject of research. While type research used in this research was descriptive qualitative research .Descriptive research done with intent provides an overview of certain social trend which exists in the community with using patterns of inductive think that is the way of thinking this to be of the particulars to general in terms of audience.
\end{abstract}

Keywords: Quo Vadis, Rational Choice, Election, Aceh Barat. 


\section{PENDAHULAUAN}

Komisi Pemilihan Umum (KPU) telah menetapkan pelaksanaan Pemilihan Kepala Daerah (PILKADA) baik Gubernur, Bupati maupun Walikota bulan Februari Tahun 2017 mendatang. PILKADA tersebut di gelar dengan secara serentak di 101 daerah yang tersebar di seluruh indoensia yakni dengan rincian 7 Provinsi, 76 Kabupaten dan 18 Kota (Sumber liputan6.com/ 15 Februari 2016).

Pelaksanaan PILKADA Gubernur, Bupati, maupun Walikota tersebut berbagai macam fenomena mesin politik yang menjadi kgtuda kenderaan dalam mencapai kekuasaan. Hal tersebut bisa dilihat baik dengan melalui jalur partai politik, maupun jalur independen. Topik yang menjadi sampling penelitian ini adalah mengkaji fenomena pemilihan kepala daerah yakni propinsi Aceh, khususnya Kabupaten Aceh Barat dalam hal Quo vadis rasional Choice dalam menentukan pilihan masyarakat di kabupaten Aceh Barat Tahun 2017.

Melihat fenomena diatas kabupaten Aceh Barat secara kasat mata, dalam hal kaca mata politik sangat unik dalam hal PILKADA 2017 mendatang, daerah yang berujung di sumatera bagian barat aceh ini menjadi sebuah fenomena lokal dengan demokrasi kaffah dalam sistem mesin politik kepemimipinan. Hal ini sangat unik dalam mencapai kekuasaan parah kandidat melalui mesin perpolitikan yang berbeda disinilah masyarakat mulai mempunyai para jagoan untuk dimenangkan para bakal calon Bupati, mulai yang disusung partai nasional, lokal dan independen. Dalam hal fenomena lain terjadi persaingan ketat dalam partai politik nasional, lokal dan independen.

Melihat kaca mata politik demokrasi sesungguhnya rakyat lah yang menentukan semua pilhan yang masuk akal bukan karena paksaan, money politik, hegemoni maupun intimidasi, dalam hal politik yang menjadi sasaran kemenangan paling tidak ada tiga faktor penentu secara realita, pertama karena mesin politik dalam hal partai yang menentukan calonnya yang disukai, kedua modal sosial masyarakat yang begitu masif dalam hal pemilihan, dan yang ketiga adalah modal kapital yang menjadi trend yakni ongkos politik yang sangat matang, (Kacung Marijan , 2006).

Dengan melihat sumber diatas maka peneliti sangat tertarik meneliti fenomena pemilihan Quo Vadis dalam hal pemilihan kepala daerah Aceh Barat Tahun 2017 mendatang. Semoga dengan melihat fenomena pemilihan kepala daerah tahun 2017 ini menjadi kedewasaan dalam masyarakat dalam memilih kepala daerah untuk kepentingan dalam bentuk proses demokratisasi di daerah yang menuju free and fair (bebas dan adil).

Dalam kajian Sosiologi perancis Piere Felix Bourdieu diantara pikiran yang melegenda adalah yakni Medan, pasar dan kapital habitus serta kekerasan simbolik dalam tulisan Agus dalam opini (lombok Post, 27/08/2016 ). Dalam Kajian ini secara teori Baurdieu bicara tentang modal ada empat macam yakni, modal ekonomi, modal sosial, modal kultural, dan modal simbolik. Menurut Baurdie kempat modal ini cukup membantu kita dalam memahami realitas pertarungan politik pada pemilu kekinian di era modern .

Pertama Modal Ekonomi. Modal yang pertama merupakan sumber daya yang bisa menjadi sarana produksi dan sarana finansial. Modal Ekonomi mencakup alat-alat produksi (mesin, tanah, dan buruh), materi (pendapatan dan benda-benda) dan uang. Maka semua jenis modal ini sangat mudah digunakan untuk segala tujuan, termasuk tujuan memenangkan pemilu, karena dalam pemilu membutuhkan biaya ongkos politik, mulai dari atribut, spanduk, baliho, tim sukses, dan sampai dengan konsultan politik.

Kedua Modal Budaya. Modal budaya merupakan keseluruhan kualifikasi intelektual yang bisa diproduksi melalui pendidikan formal maupun warisan keluarga, seperti kemampuan menampilkan diri didepan publik, pengetahuan dan keahlian tertentu hasil pendidikan formal seperti gelar keserjanaan maupun pengalaman dalam memimpin suatu organisasi negara. Pertarungan politik dalam pemilihan presiden, gubernur, kepala daerah baik bupati maupun walikota. Modal budaya juga menjadi tolak ukur masyarakat yang menentukan pilihan karena 
dengan melihat kapabilitas seorang aktor dilihat ketika berkomunikasi, pendekatan melalui intelektual, dengan berbagai macam, baik melalui propoganda media, maupun gaya dalam komunikasi politik yang dalam hal ini untuk pencitraan diri di depan publik juga menjadi penentuan gaya menuju kemenangan seorang candidat calon dalam pertarungan politik dalam hal meraut masa.

Ketiga Modal Sosial. Modal Sosial merupakan jaringan hubungan seebagai sumber daya untuk penentuan kedudukan sosial dan modal sosial tersebut akan menghasilkan pertarungan kekuasaan simbolik. Dalam realitas modal sosial ini peran polah pikir seorang calon pemimpin juga diutamakan dan menjadi penting dalam hal mencari kekuasaan, hal ini melihat masyarakat semakin cerdas untuk menentukan pilihan, sehingga kedekatan emosional juga menentukan untuk multi player efek dalam hal meraut dukungan politik dalam pemilihan pemimpin diera demokrasi baik lokal nasional.

Ke Empat Modal Simbolik. Modal Simbolik adalah pimpinan tertinggi pada organisasi masyarakat, kendaraan mewah, foto dengan pakaian muslim yang taat, keturunan langsung dari pimpinan besar perna memiliki pengaruh, bangsawan, raja, dan ningrat dalam kekayaan.

Dalam pertarungam politik, biasanya simbol memiliki kekuatan yang untuk merekontruksi realitas, yang pada akhirnya mampu menggring opini untuk memilih kandidat tertentu. Dengan menlihat fenomena diatas telah terjadi pertarungan dalam hal pemilihan kepala daerah Kabupaten Aceh Barat Baik melalui dukungan partai politik nasional, partai politik lokal dan idependen. Selain kajian diatas dalam hal ini, prof Kacung Marijan dalam bukunya Demokratisasi Di daerah Pelajaran dari Pilkada Lagsung hanya membagi tiga peta kekuatan dalam hal menuju kepala daerah bisa memenangkan dalam pemilihan. Yaitu modal sosial, modal kapital dan modal politik (Kacung Marijan, 2006) . Dalam kajian ini Aceh Barat dalam pemilihan juga akan menimbulkan efek dalam hal tiga faktor ini, hal lain dalam perilaku memilih lebih melihat sosok simbolik dalam menentukan rasional Choice yang ditawarkan Oleh Bourdieu.

\section{METODE PENELITIAN}

Metode yang digunakan dalam penelitian ini adalah metode penelitian kualitatif, dimana yang dicari adalah pemahaman atas suatu fenomena sosial, sehingga yang menjadi fokus utama adalah memperoleh pemahaman atas tindakan dan makna gejala sosial dalam sudut pandang subyek penelitian.

Sementara tipe penelitian yang digunakan dalam penelitian ini adalah penelitian deskriptif kualitatif. Penelitian deskriptif dilakukan dengan maksud memberikan gambaran mengenai gejala sosial tertentu yang ada dalam masyarakat dengan menggunakan pola berpikir induktif yaitu cara berfikir dari hal yang bersifat dari khusus ke umum dalam hal khalayak. Selain itu penelitian deskriptif kualitatif juga membicarakan hal indifidu, kelompok, masyarakat dan kelembagaan ( Burhan Bungin, 2007).

Adapun teknik penelitian yang dilakukan peneliti adalah dengan cara pengamatan, teknik pengamatan memungkinkan dan mengamati sendiri, kemudian mencatat perilaku dan kejadian sebagaimana yang terjadi pada keadaan sebenarnya (Moleong, 2013).

\section{HASIL DAN PEMBAHASAN}

Fenomena dalam penentuan pilihan masyarakat Aceh Barat pada pemilihan kepala daerah Tahun 2017 mendatang masyarakat dalam hal ini akan menentukan pilihannya. Hal tersebut untuk melihat rasional chioce (pilihan tepat yang masuk akal) masih mengambang. Maka dalam hal peneliti ingin melihat fenomena pemilihan kepala daerah dalam konteks Quo vadis Rasional Choice dalam Pemilihan Kepala Daerah atau Bupati Kabupaten Aceh Barat Tahun 2017. 
Pemilihan Kepala Daerah yang dalam hal ini PILKADA serentak dilakukan oleh Negara Republik Indonesia dalam hal ini lewat panitia penyelenggara Pemilihan Umum (PEMILU) sudah memulai Start penerimaan bakal calon, yang diusaung oleh partai politik baik partai nasional, lokal maupun jalur independen. Dalam penelitian ini, peneliti konsentrasi melihat fenomena rasional Choice dalam penentuan pilihan masyarakat di kabupaten Aceh Barat. Bakal Calon Kepala Daerah yang akan bertarung dalam pemilihan ini telah tampak menawarkan diri ke masyarakat dalam hal poster spanduk, baliho, Kantor Tim Sukses pos pemenangan, maupun tim sukses geriliya dengan menawarkan setiap calon baik melalui media elektronik maupun media sosial.

Adapun Bakal Calon yang akan bertarung dalam pemilihan Kepala Daerah, dalam hal ini mempunyai tiga calon, baik yang didukung partai Nasional, Partai Lokal, Dan Jalur Independen. Adapun Calon Yang Didukung Oleh Partai Nasional adalah DR (Hc). H. T. Alaidinsyah, Dan wakil Bupati H. Kamarudin, SE Partai politik pendukung semua yang mempunyai suara di Dewan Perwakilan Rakyat Kabapaten (DPRK) Kota Aceh Barat antara lai adalah Partai Amanat Nasional (PAN), Partai Golongan Karya (GOLKAR), Partai Demokrat, Partai Persatuan Pembangunan (PPP), Partai Demokrasi Indonesia Perjuangan (PDI-P), Partai Kebangkitan Bangsa (PKB), Partai keadilan Sejahtra (PKS), Dan Partai Nasional Demokrat (NASDEM). Calon yang didukung Partai Nasional ini Incumbent dan mempunyai selain modal partai politik yang kuat, juga modal kapital yang kuat . Sedangkan partai Lokal yang diusung antara lain adalah H.Ramli, MS dan Wakil Bupati H. Banta Puteh Syam. Calon Dari partai lokal ini selain gerakan akar rumput yang kuat, dan saat ini partai lokal dalam hal Ini Partai Aceh Juga masih mendominasi kekuasaan di propinsi aceh dalam hal baik gubernur maupun walikota maupn Bupati, DPRA/DPRK karena partai lokal ini mempunyai sebuah nilai sejarah yang panjang perjuangannya bagi bangsa rakyat aceh, hal tersebut tertuang dalam Undang-Undang Pemerintah Aceh No. 11 Tahun 2006 . Dengan Melihat hal fenomena diatas Bakal Calon Bupati yang diusung oleh partai lokal ini juga bisa memenangkan dalam pemilihan kepala daerah kabupaten aceh barat pada tahun 2017 mendatang, dan calon tersebut juga perna menjadi bupati pada periode 2007 -2012. Adapun bakal calon bupati yang naik dari jalur independen adalah Calon Bupati Fuad Hadi, SH., MH dan Calon wakil bupati bakal calon dari independen tersebut juga bisa merai kemenangan hal tersebut bisa dilihat ketika pemilihan Gubernur Aceh pada Tahun 2007 yang lalu bahwa jalur independen bisa memenangkan dalam pilkada dan mengalahkan semua bakal calon yang didukung oleh partai politik.

Peta praktis dalam mencapai kekuasaan menurut sosiolog prancis Piere Felix Bourdieu dalam politik kekinian paling tidak ada empat macam yang untuk mencapai kekuasaan, antara lain modal ekonomi, modal budaya, modal sosial, dan modal simbolik. Semua peran dari empat tersebut mempunyai kepentingan tersendiri untuk melengkapi amunisi dalam menacapai kekuasaan. Dalam kontelasi politik untuk menuju kemenangan sungguh sangat mahal harganya dalam hal ini ongkos politik, maka dalam hal ini modal kapital sangat berperan aktif untuk mencapai tujuan, karena semua bakal calon, perlu poster baliho, spanduk, pos rumah pemenangan, tim sukses, pembayaran saksi, konsultan politik, media sebagai alat untuk propoganda dalam marketing politik menghegemoni masyarakat dalam mempengaruhi pilihan dalam pemilu persepsi politik diartikan sebagai money politik padahal yang terjadi fakta realitas ongkos politik yang menjadi mahal (High Cost) dalam menuju pintu kekuasaan . Kedua, seorang calon harus mempunyai modal budaya yang kuat, modal budaya yang dimaksud adalah pengetahuan intelektual yang menapis isu dalam hal komunikasi politik yang mencari jalan keluar dari problem masyarakat dalam hal ini pendidikan juga menentukan track record dalam mencapai kekuasaan. Sehingga problem masyarakat agar supaya bisa diselesaikan dalam hal menacapai tujuan yang dinginkan oleh masyarakat. Ketiga Modal Sosial hal ini sangat penting ketika seorang bakal calon bupati tanpa modal sosial yang kuat jangan harap kemenangan akan timbul dalam pemilihan, karena pendekatan sosial kepada masyarakat juga 
penting, tren popularistas di masyarakat, sering turun kebawa blusukan sehingga setiap calon perlu di perbincangkan di area masyarakat dalam hal ini apa yang mudah diingat dalam program yang menyentu masyarakat. Modal sosial sangat beragam, modal sosial dengan partai politik, dengan komunitas, dengan organisasi, baik dalam keluarga maupun indifidu sehingga dengan gerakan modal sosial otomatis setiap calon akan sangat mudah menuju kemenangan. Ke empat terakhir adalah modal simbolik, Modal simbolik seorang bakal calon kepala daerah harus bernilai dalam bahasa klasik primus inter pares (minimal kepala suku), karena mempunyai pengaruh yang kuat, ningrat, raja, mempunyai wibawa, kaya raya, yang disegani sehigga dalam pelaksanaan pilkada sungguh sangat mudah mempengaruhi masa ketika seorang bakal calon bupati kalau mempunyai modal simbolik yang kuat.

Fenomena dengan melihat realita diatas bakal calon bupati aceh barat untuk Tahun 2017 sudah sangat tampak siapa yang akan menang dalam pertarungan tersebut, sehingga Quo Vadis Rasional Choice ini bisa menjadi peneliti menarik dalam hal gaya yang disukai oleh masyarakat. Untuk menentukan pilihan tersebut sangat di tantang fenomena sosial di kabupaten Aceh barat dalam pemilihan, Pilihan Masyarakat dalam perumpamaan dalam kaca mata politik ketika masyarakat memilih partai politik yang di calonkan oleh partai nasional Dr.(Hc) H.T. Alaidinsyah dan H. Kamarudin, SE yang memenangkan dalam pilkada Tahun 2017 maka kebenaran rasional choice lebih cendrung kesukaan partai nasional. Selanjutnya ketika bakal calon Bupati yang di menangkan partai lokal oleh bapak H. Ramli, MS dan Wakil Bupati H. Banta Puteh Syam menang maka rasional choice masyarakat aceh barat lebih senang dengan jiwa primondialismenya yakni lebih cendrung senang pada partai lokal. Selanjutnya yang trakhir ketika bakal calon bupati aceh barat dimenangkan oleh Calon Independen Bapak Fuad Hadi, SH.,MH dan wakil Bupati Aceh barat dr. Muhammad Arif, maka rasional choice masyarakat aceh barat lebih senag netral dan non politis dalam mencari calon pemimipin bupatinya.

Sehingga dengan hal ini peneliti mempunyai catatan penting dalam hal pemilihan kepala daerah kabuapten aceh barat di Tahun 2017 mendatang, sehingga dalam hal ini masih mengamati maka dalam penelitian ini mengambil judul "Quo Vadis Rasional Choice Dalam Pilkada Aceh Barat Tahun 2017). Quo Vadis yang bisa diartikan dalam bahasa indonsia terjemahan makna "kemana engkau pergi". Dalam kontek pemilihan kepala Daerah aceh barat pada tahun 2007 mendatang kemana arah pilihan masyarakat yang dipilih bakal calon bupati, apakah yang diusung partai nasional, lokal atau independen, untuk melihat fenomena tersebut hasil fenomena ini bisa dilihat ketika pemenangan yang akan disaksikan pada Tahun 2017 yang akan datang. Semoga Pilkada aceh barat tahun 2017 ini berbobot dan bekualitas tanpa money politik, kekerasan sehingga betul jujur dan adil (jurdil), sebagai negarawan harus menciptakan pemilu yang free and fair (bebas dan adil).

\section{a. Bakal Calon Bupati Dan Wakil Bupati Yang Bertarung Pada Pilkada Kabupaten Aceh Barat 2017}

Pemilihan Kepala Daerah (PILKADA) Bupati Kabupaten Aceh Barat Tahun 2017 Bakal Calon Telah mendaftar memulai pendaftaran ke Komisi Independen Pemilih. Di bawah ini daftar nama Bakal Calon bupati yang akan bertarung Dalam Pemilhan Kepala Daerah Kabupaten Aceh barat. Baik melalui partai politik nasional, partai politik lokal, dan Jalur Independen.

\begin{tabular}{|c|l|l|}
\hline No & $\begin{array}{l}\text { Nama Pasangan Bakal Calon } \\
\text { Bupati Dan Wakil Bupati 2017 }\end{array}$ & \multicolumn{1}{c|}{ Partai Pendukung } \\
\hline 1 & $\begin{array}{l}\text { Dr. Hc. H.T. Alaidinsyah dan H. } \\
\text { Kamarudin SE }\end{array}$ & $\begin{array}{l}\text { Partai Amanat Nasional, Partai Golongan Karya, } \\
\text { Partai Demokrat, Partai Persatuan Pembangunan, } \\
\text { Partai Demokrasi Indonesia Perjungan, Partai }\end{array}$ \\
\hline
\end{tabular}




\begin{tabular}{|l|l|l|}
\hline & & $\begin{array}{l}\text { Kebangkitan Bangsa, Partai Keadilan Sejahtera, } \\
\text { Dan Partai Demokrat (Partai Nasional) 8 partai } \\
\text { Pendukung. }\end{array}$ \\
\hline 2 & $\begin{array}{l}\text { H. Ramli, MS dan H. Banta } \\
\text { Puteh Syam }\end{array}$ & Partai Aceh (Lokal) 1 Partai Pendukung \\
\hline 3. & $\begin{array}{l}\text { Fuad Hadi, SH.,MH dan dr. } \\
\text { Muhammad Arif }\end{array}$ & Independen (Non partai) \\
\hline
\end{tabular}

Gambar Sumber tabel diatas dikutip dari Media Indoensia rabu 28 september 2016 dan KIP Aceh Barat 27 September 2016 diunduh sabtu 15 Oktober 2016.

\section{Calon Dukungan Partai Nasioanl}

Gambar Dalam iklan spanduk pendukung dari Calon bupati yang didukung oleh partai nasional (incumbent) yang bertarung dalam pemilihan kepala daerah kabupaten aceh barat di Tahun 2017 yang didukung oleh Partai Nasional. Dalam hal ini antara lain yang Partai Amanat Nasional, Partai Golongan Karya, Partai Demokrat, Partai Persatuan Pembangunan, Partai Demokrasi Indonesia Perjuangan, Partai Kebangkitan Bangsa, Partai Keadilan Sejahtra dan Partai Nasional Demokrat.

Dengan Melihat fenomena politik diatas Calon Bupati DR.HC. H.T. Alaidinsyah, dan Calon wakil Bupati H. Kamarudin, SE, Partai Politik yang didukung oleh partai nasional semua mempuyai kursi di Dewan Perwakilan rakyat kabupaten DPRK Aceh barat Di parlemen. Melihat Peta realitas politik partai yang didukung oleh partai nasional ini cukup berpeluang menang karena dengan melihat partai pendukung yang ada cukup meyakinkan karena mesin partai penggerak juga mempunyai peta kekuatan, akan tetapi dalam hal politik ini tidak menjadi sebuah mustahil juga bisa kalah dalam pemilihan, fenomena ini bisa dilihat ketika pemilihan kepala daerah gubernur DKI Jakarta pada Tahun 2012 Kompas Minggu (20/03/2016). Justru Partai politik yang di dukung oleh partai politik yang mayoritas tidak menang dalam hal pemilihan gubernur DKI jakarata di Tahun 2012 yang telah lalu. Fakta tersebut bisa dilihat ketika kemenangan Jokowi-Ahok Atas Kekalahan Fauzi Bowo dan Wakilnya, karena fakta lembaga survai hari itu Fauzi Bowo (incumbent), mendapat 43 Persen pemilih, Dan Joko widodo hanya 7 Persen dan hasil kemudian di pemilihan kepala daerah Jokowidodo yang menang dalam pemilihan Gubernur DKI jakarta.

Dengan Melihat fakta politik diatas dalam hal ini, kabupaten Aceh barat juga bisa mengalami yang sama dengan diatas, akan tetapi dalam hal ini kultur dan budaya masyarakat aceh barat sangat bedah dalam hal Rasional Choice Pemilihan Kepala Dearah. Fakta tersebut akan dibuktikan kemenangan di Februari Tahun 2017 Mendatang. 


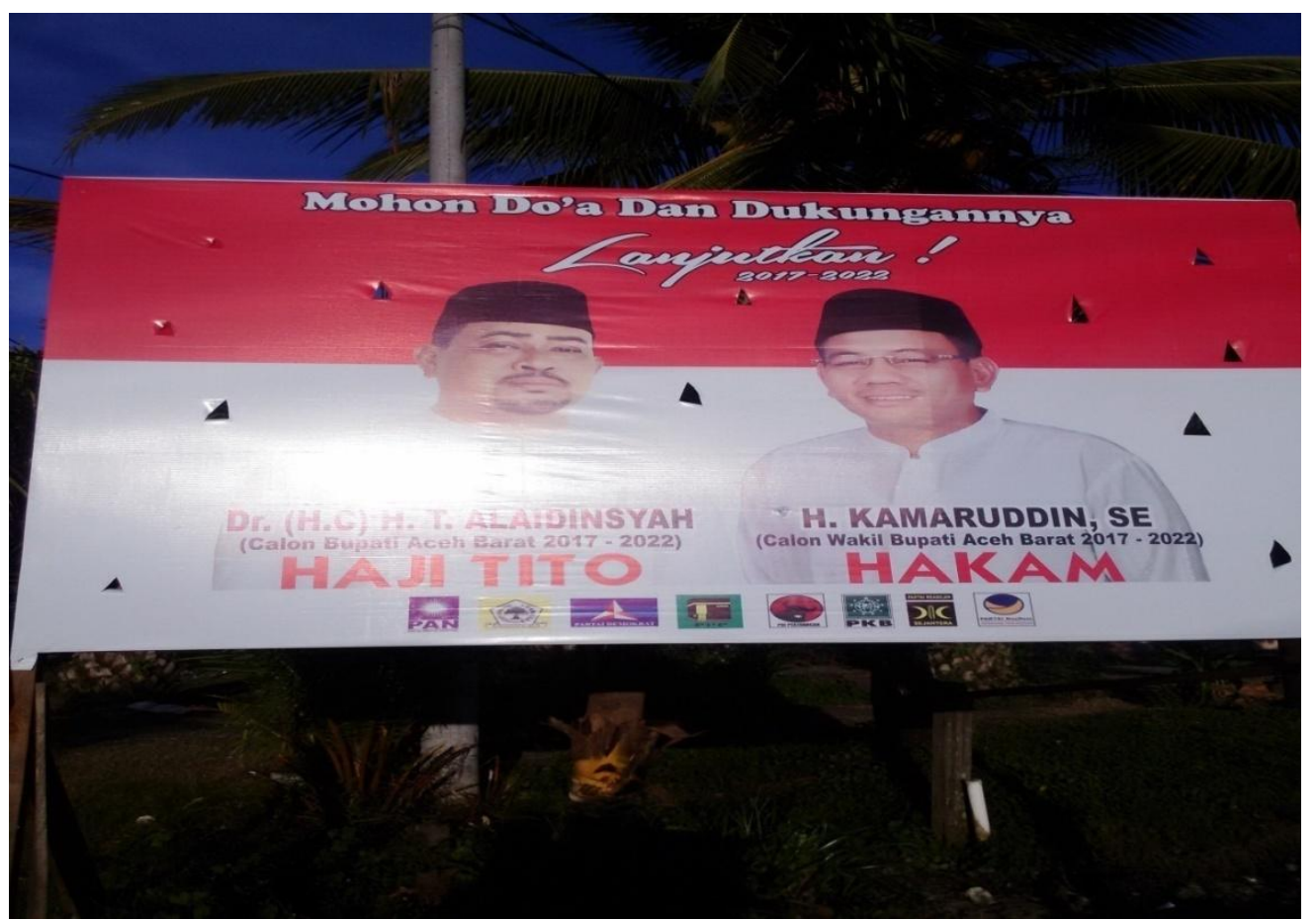

Gambar nomor 1 adalah calon yang di dukung oleh Partai Nasional Dr. Hc. H. T. Alaidinsyah (calon Bupati) dan H. Kamruddin, SE (Wakil Bupati) Foto diambil September 2016 Dijalan Raya Nasional Meureubo Aceh Barat .

\section{Calon Dukungan Partai Lokal.}

Partai politik lokal dalam pemilihan kepala daerah di Kabupaten Aceh Barat di Tahun 2017 juga mempunyai bakal calon untuk diusung dalam hal pertarungan politik, Dalam hal Bakal Calon Bupati Bapak H. Ramli, MS dan Bakal Calon Wakil Bupati adalah H. Banta Puteh Syam Meraka ini diusung oleh partai politik lokal yakni partai Aceh.

Peta Kekuatan dengan melihat fenomena Partai yang diusung oleh partai politik lokal ini juga bisa memenangkan dalam pemilihan kepala daerah kabupaten Aceh barat pada Tahun 2017 mendatang. Dengan melihat kultur ke acehan partai ini juga bisa memenangkan dalam hal pilkada aceh barat di asumsikan selain punya akar rumput yang kuat bakal calon tersebut perna juga menjadi bupati aceh barat pada periode 2008 sampai 2012 hal ini bisa dilihat dalam hal dengan ego sentris masyarakat lokal yang sangat begitu antusias dalam hal partai politik lokal dengan khas ke Acehan. Untuk melihat realitas tersebut juga peneliti belum bisa menyimpulkan parah kemenangan yang mutlak tapi dalam hal ini partai lokal juga bisa memenangkan pada pilkada 2017 mendatang, dan untuk pembuktian akan dilihat dalam rasional Choice masyarakat pada pemilihan kepala daerah februari 2017. 


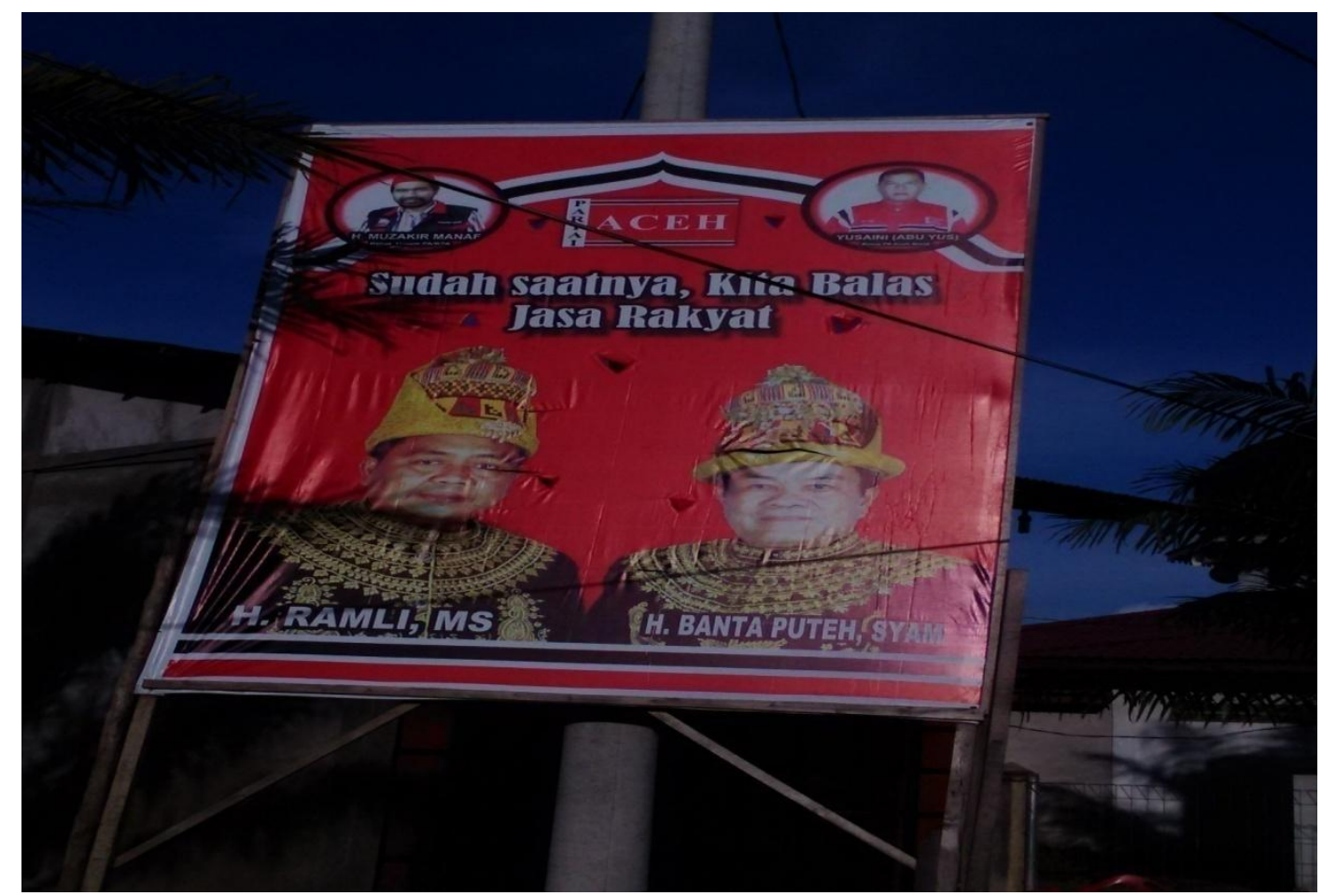

Gambar nomor 2 adalah calon yang di dukung oleh Partai Lokal H. Ramli, MS (calon Bupati) dan H.Banta Puteh Syam (Wakil Bupati) Foto September Tahun 2016 di Salah jalan Nasional Meurebo Aceh Barat .

\section{Calon Dukungan Lewat Independen.}

Bakal Calon Bupati Aceh Barat pada Tahun 2017 juga ada yang melalui jalur independen. Calon bakal bupati tersebut adalah Bapak Fuad Hadi, SH.,MH dan Bapak Calon wakil Bupati adalah dr, Muhammad Arif. Bakal Calon Bupati Aceh Barat yang jalur independen ini memuat jargon semangat aksi nyata buat aceh barat, yang tua sudah perna saatnya yang muda menjadi pemimpin.

Peta Kekuatan Calon kepala daerah melalui jalur independen juga bisa memenangkan dalam pemilihan kepala daerah Di Kabupaten Aceh Barat pada Tahun 2017 mendatang, hal tersebut bisa dilihat ketika calon gubernur aceh pada Desember 2006 yang dilakukan oleh dr. Irwandi Yusuf, M.Sc dan Muhammad Nasar, S.Ag bisa mengalahkan beberapa calon gubernur yang diusung oleh partai politik detik news (12/12 2016). Fenomena yang terjadi pada awal calon independen di indoensia menang dan non partai, karena hal ini masyarakat menilai partai politik tidak lagi menjadi cerminan perwakilan rakyat, masyarakat lebih cendrung melihat yang netral dan independen. 


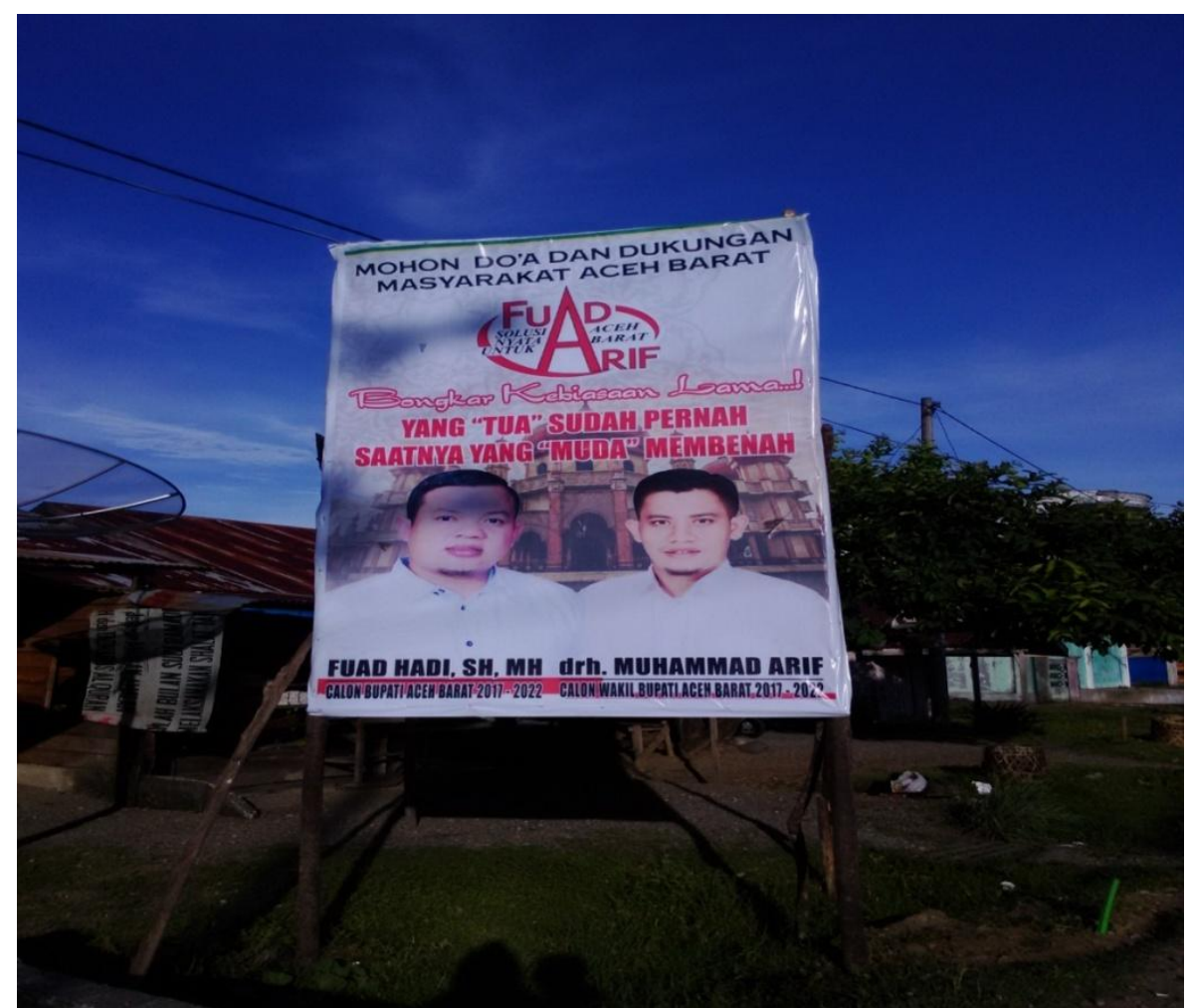

Gambar nomor 3 foto Calon Bupati Wakil Bupati Dari Independen Fuad Hadi, SH.,M.Hum, dan drh. Muhammad Arif Untuk Pilkada 2017 di salah satu Jalan Raya Meurebo Aceh Barat Minggu 2 Oktober 2016.

\section{SIMPULAN}

Pemilihan Kepala Daerah (PILKADA) Kabupaten Aceh Barat Tahun 2017 mendatang mempunyai tiga pasangan bakal calon bupati, yaitu Dr.(Hc) H.T. Alaidinsyah, dan calon wakil bupati $\mathrm{H}$. Kamarudin, SE calon tersebut di dukung oleh partai nasional antara lain PAN, GOLKAR, DEMOKRAT, PPP, PDIP, PKB, PKS dan NASDEM. Sedangakan yang kedua adalah bakal calon yang didukung oleh partai lokal adalah bakal calon buapti H. Ramli, MS dan bakal calon wakil bupati H. Banta Puteh Syam dan partai pendukung adalah PARTA ACEH. Selanjutnya yang ketiga bakal calon bupati aceh barat adalah dari jalur independen yaitu bakal calon bupati Fuad Hadi, SH.,MH dan bakal calon wakil bupati adalah dr, Muhammad Arif.

Untuk melihat fenomena diatas masyarakat aceh barat akan menentukan pilihan pada bulan Februari Tahun 2017 mendatang. Dengan demikian pilkada aceh barat kali ini sungguh sangat beragam bakal calon mulai dukung mendukung, sehingga dari ketiga calon tersebut akan menentukan nasip aceh barat kedepan, maka dalam hal ini rasional choice aceh barat kedepan bisa dilihat ketika kemenagan dari ketiga calon tersebut. Baik melalui partai nasional, partai lokal, maupun jalur independen.

Pertama masyarakat aceh barat akan diuji kedewasaan rasional choice (pilihan yang masuk akal) dalam pemilihan kepala daerah, apakah memenangkan partai nasional, partai lokal atau independen. Dalam hal ini para kandidat siapa pun yang meneng harus menjadi pemimpin yang menaungi hati rakyat aceh barat disinilah aceh barat akan menampakan kedewasan yang menuju pilkada free and fair (bebas dan adil).

Kedua, parah bakal calon siapa yang menang harus menujukan jiwa negarawan untuk menyatukan lawan menjadi pemersatu untuk membangun aceh barat, dan juga bagi yang bakal calon mengalami kekalahan harus menerima dengan senang hati bukan menjadi penentang arus 
kebijakan sehingga aceh barat bisa maju dan mandiri dalam hal pilkada dan contoh buat Indonesia.

\section{REFERENSI}

Bungin. Burhan. 2007. Penelitian Kualitatif Komunikasi, Ekonomi, Kebijakan Publik, dan Ilmu Sosial Lainnya. Jakarta: Kencana Prenada Media Group.

Dounloud. Kip-Acehbaratkab.go.id /2016 Di Aceh- barat uji-mampu-baca al-qur'an, Tiga Pasangan Kandidat Di Aceh Barat Uji mampu Baca Al- Qur'an. 27 September 2016. Diunduh, Tanggal 15 Oktober 2016

Dounloud. www.kompas.co.id/ minggu 20 Maret 2016. Diunduh, Sabtu 15 Oktober 2016

Dounloud. Portalsatu.com/read/politik 29 Juli 2016. Diunduh, Sabtu 15 Oktober 2016

Dounloud.www.detiknews.com berita berita irwandi-nazar-bukti-pilkada aceh-demokratis . Kemenangan Irwandi-Nazar bukti Pilkada Aceh Demokratis, selasa 12 Desember 2016. Diundu.S Minggu 16 Oktober 2015

Dounloud .Sumber liputan6.com/ 15 februari 2016. Diunduh Tanggal 24 September 2016

Dounloud. Sumber Media Indonesia. www.mediaindoensia.com news. Tes baca al Qur'an Di Aceh barat. 28 September 2016. Diunduh Tanggal 15 Oktober 2016

Marijan Kacung. 2006. Demokratisasi Di Daerah Pelajaran Dari Pilkada Secara Langsung. Surabaya: Pustaka Eureka dan PusDeHam.

Moleong J. Lexi. 2013.Metodologi Penelitian Kualitatif Edisi refisi. Bandung: Remaja Rosda Karya.

Undang-Undang Nomor 11 Tahun 2006 